\title{
EDUCATIONAL AIMS AS KEY COMPONENTS \\ OF EDUCATION (A METHATEORIES CONCEPT \\ OF PHILOSOPHY OF EDUCATION \\ IN THE EAST EUROPEAN PEDAGOGY)
}

\author{
Štefan Chudý \\ Alena Jůvová \\ Pavel Neumeister \\ Denisa Snopková
}

\begin{abstract}
Currently, the most important thing for a young person is to be part of "something", belong to society, be active, competent, keep oneself. The person can set goals to be reached. Education can be one of the goals. Even pedagogy seeks targets to be reached. The general objectives of education represent the norms of social activities. Society determines what should be taught. However, it is not related only to education but also to other scientific disciplines. The article deals with educational goals, their definition, history and development as well as the normative approach - a subject of qualitative research. The research was carried out in the form of discourse analysis and comparative analysis as a method and refers to the classification of educational goals in the Czech and Slovak pedagogy as a result of the analyses. It also introduces taxonomy of educational goals.
\end{abstract}

\section{Key words}

Educational goal, educational processes, axiological approaches, taxonomic classification, Czech pedagogy, Slovak pedagogy, discourse and comparative analyses.

\section{INTRODUCTION}

People as creative beings find the meaning of their endeavour in aiming towards the future and towards perfection. The meaning of their lives is defined by the goal they want to achieve. To be able to reach that goal, one needs to understand socio-cultural conditions, values, behavioural patterns, human relationships, their rights and obligations, evaluation principles and ideals. The basic normative orientation is obtained in the family, school and educational institutions, in formal and informal groups. A young person needs role models 
and ideals to satisfy their needs and desires. They represent pillars and aim towards social values. A sense of values is obtained through education and determination of educational goals in the context of educational process as an integrated and systemic activity leading to formation of moral aspect. It is an anthropological-axiological aspect where educational goals are the key elements. A great number of authors (Bábosik, Pintés) discuss intentionality and determination of goals as a basic category of educating. They see educational goal as a cornerstone of the conception of educational process and determination of its focus and content.

At the turn of the $21^{\text {st }}$ century the emphasis is put on developing a fullyfledged and capable personality willing to participate in its life as well the life of others. A fully-fledged personality is characterized by certain features, such as authenticity, creativity, freedom, responsibility, integrity. Therefore it is obvious that we have to look at the goal and its determination, definition, and topicality from different perspectives. The most common and general definition views educational goal as an ideal (cf. Kučerová, 1996, Pintés, 2004, Chudý, 2006). Brezinka (1991, p. 15) describes ideal as a primary activity and a link to the goal. This primary activity is characterized in pedagogical science as a priority category. Kročková (in Gogová, 2004, p.52) sees ideal as an image of a person. This image is a bearer of important values. Educational ideals as general notions about people are influenced by a number of social, historical, philosophical and educational factors. Changes in the society affect these ideals and images. A great variety of social changes has caused a great variety of ideals which are based on real notions but often on unreal ones. Distinction is possible when comparing characteristics such as world view, values or sexual orientation. In every society there are tendencies which lead to creating the foundations of human ideal which then represents the notion about the image of a person. The more elaborate such an image is, the closer it is to be reached. The ideal of education and educating according to normative definitions (Millennium Project, 2000) is a personality which is good (honest, decent), wise (educated and creative), active (independent and hard-working) and happy (well-balanced and healthy). Based on this, human personality is an articulation of value systems and life orientation. The intersection of these axiological systems and orientation can be called life philosophy, ideology or world view. It is a sum of principles, believes and opinions which determine personal or social activities. Individual world view stems from target domains of education (cf. Švec, 1995, White Paper, 2001, Millennium, 2000) Brezinka (1996, pp. 1718) sees world view as a basis of educational goal and human activity.

Among the most important activities necessary for biopsychic development the best defined is the value nature of educational ideal as accepted by the World Conference on Education for All. These life goals are: to survive, to fully realize one's abilities, to live and work in dignity, to participate in society development, to improve the quality of life, to make informed decisions, to continue learning (UNESCO, 1993, p. 78 in Švec, Š., 2001, p. 14). 
These ideals represent a model of real life ideals in the process of life-long shaping of human personality - general subject of an input on discourse analyses. Ideals and visions are thought-transformed notions about personality perfection and are the basis for defining general educational goals. General educational goals represent the norms of activity of a particular society transferred to education. Ideals set direction and orientation for other secondary goals: general, individual, concrete. General educational goals are examined by pedagogical teleology which interprets systemization and classification of goals along with tendencies of axiological-normative aspects of goals. It explains criteria and functions of goals, their optimization and incorporation in pedagogical theory and practice. General goals allow us to derive secondary goals - individual goals which determine the direction of educating. When unravelling general and individual goals, it is vital to define the goal on the level of pedagogical teleology and the theory of education.

\section{SUBJECT OF RESEARCH 1 - NORMATIVE APPROACH AND DEFINITION OF EDUCATIONAL GOALS IN TRADITIONAL CZECH AND SLOVAK PEDAGOGY}

The educational goal and ideal has been presented in global determination. In contemporary Czech and Slovak pedagogy it can be found especially in the areas of philosophy and the theory of education. Both disciplines stem from the philosophical basis, teleology. Etymology describes teleology as a science about a goal as seen in Višňovský (1998, p.127). Janiš, Kraus, Vacek (2008 p. 41) describe pedagogical teleology as a fundamental discipline of the philosophy of education which stems from the purpose of educational goal. This purpose is visible in actual interests and abilities. Kotchy (in Pintes, 2005, p.14) depicts teleology as a science about goals which deals with the most general description of educational goals. In compliance with this definition we define the first and the second part of discourse analysis:

- Analyzing and observing bases of global trends in determination of education.

"Analyzing the function of goal and its context.

Analyzing the relationship between formulated and accomplished goal.

The most precise definition of pedagogical teleology can be found in Štverák's General and Comparative Pedagogy (Obecná a srovnávací pedagogika 1997 pp. 45-46). It is here defined as a fundamental discipline of pedagogy which determines educational goals.

Before defining educational goal as a specific category in the context of axiological nature of education, we have to present it as a result of numerous bases: historical, methodological and methodical, political, global, philosophical. 
The historical basis of educational goals is closely connected with human evolution and cultural conditioning of the society and education. Educational goals change with periods, nations, philosophy and culture (Jůva and Jůva, 1997, p. 34). The outlined knowledge brought by studying historical pedagogical sources consists of determinants of past educational goals and components of future educational goals. These components carry certain information about the past, values and cultural roots and form a basis for the understanding of new challenges and concepts in future education. Educational goal is not a valueunifying and value-erasing process; on the contrary, it continues and links together thoughts, ideals and concepts.

Axiological analysis helps decipher cultural specifications and educational elements in the process of socialization. From the viewpoint of goals, it is assimilation and highlighting the uniqueness of personality and culture. Methodological and methodical bases of educational goals are perceived as fundamental when outlining general and specific educational goals. Determination of educational goals from the viewpoint of methodology stems from the educational conception of contemporary pedagogy, namely from the theory of education and philosophy of education. Methodical focus of the conception of educational goals is based on the personality criteria of the educated (personality peculiarities, age, etc.) as well as on the nature of educational process and its content (developing goal elements of education). Political bases of educational goals constitute the cornerstone when outlining education as a social (political) process. Since Maria Theresa, educational goals, focus and process have been the key elements of political power. The $21^{\text {st }}$ century started a new concept of educational goals in local conditions in the EU context (UNESCO, 1997, Millennium, 2000, The White Paper 2001, RVP, 2004, 561/2004 etc.). The programmes specify the idea and purpose of national programmes in individual countries and general educational goals. In every society there are tendencies leading to a creation of a basic human ideal which represents the image of human perfection (Gogová, Kročková, 2004, p. 53). Global bases of educational goals stem from reflecting contemporary society and life reality. Globalization tendencies are mirrored in the concept of educational process. A number of authors point at the shift in educational conception (e.g. Střelec, 2005) and at a list of typological problems of the period (e.g. Kudláčová, 2004, 2007, Lorenz, 1973, Skalková, 1993) which endanger the originality of human personality and its value orientation. Other authors (e.g. Rosa 2000) see a positive aspect of globalization in contemporary education and its goals. Philosophical bases are the key elements when outlining, creating and enforcing educational goals. The perfect image of the goal is the cornerstone of the quality of the educational process. Models, ideals and concepts of individual philosophy (world view) vary in values, value system and the understanding of the meaning of life.

Brezinka (2001, p. 209) sees the philosophical basis of educational goal in the decision-making process concerning education in life. The analysis is performed based on inter-value approach in which the intensity and motivation 
power towards values is described. According to Brezinka the goal is represented by the outcome of the process which is supported by educational procedures (taken from Brezinka, 1996, p. 35). The category of goal is understood as a result of pedagogical endeavour which - supported by educational procedures - heads toward personality development. Goals can be developed in a "traditional way" (1960s) where education is a versatile, harmonious developing activity, however, these goals are based on the content of education and goal elements. These are not goals meant for the development of each personality but goals emerging from the society and goals which are primarily set by the society in a relevant state of evolution.

Such formulated general educational goal is always specified by the goal elements of education (intellectual education, moral education, aesthetic education, working and polytechnic education, physical education, military education, etc.) which relate only to the content aspect of education which is determined only by the goals of society. In the realization part of education the emphasis is put on one-sided, incomplete approach focused merely on the content aspects and the formative aspect of personality development in all its complexity. Individuality development is neglected or underrated. When discussing educational goals, this traditional approach to the understanding of general goal is often criticised (c. f., Višňovský, 2004, Švec, 2001) and the goal elements scheme is not consistent with the development aspect of personality in contemporary education. A new approach to general educational goals was defined (model of four pillars of Delors' concept of education).

1. To learn to know nature, cultural and personal naturalness.

2. To learn to act.

3. To learn to evaluate.

4. To learn to make oneself understood and understand others and oneself.

As the above mentioned goal elements are less considered in the educational process it is our duty to provide a brief overview.

The goal to learn to act expresses the ability to learn to change efficiently with the help of practical skills, improve oneself, solve one's own and other people's problems. The goal is to teach an individual to cooperate, organize, monitor one's as well as other people's activities, reflect one's and other people's results, control oneself, take responsibility, restore cultural traditions, help people etc. Learning to act represents acquiring social skills, especially pro-social skills. The taxonomy of roles for pro-social behaviour, which is the highest form of behaviour, has been outlined by R. R. Olivar. Pro-social behaviour is the counterbalance to egoism, selfishness, indifference, hostility. Pro-social behaviour consists of activities leading to mental, social and material support of another human being. It is a kind of behaviour where help is the most common display of behaviour in difficult situations when a person acts according to social-moral values. These mentioned values are not inborn, they must be consciously developed. 
The goal to learn to evaluate helps the individual to acquire and use procedures in evaluating things, phenomena, people, ideas based on a pre-defined value orientation. This requires a continual development of social attitudes, empathy, interests and needs with the ability to assign value to things, people, and phenomena. Individual's value orientation should be based on a positive relationship to nature, society, culture, material values and to oneself. It should motivate pupils to new values connected with the issues of contemporary civilization and preservation of a healthy lifestyle. The above mentioned factors condition updating of certain values and value relations of pupils to human life.

The goal to make oneself understood and understand others and oneself is essential for social literacy. Mother tongue, foreign languages and computer language are ways of communicating and their command creates prerequisites for active participation of the pupil in communication and at the same time supports mutual understanding between people, groups, and nations ${ }^{1}$.

\section{SUBJECT OF RESEARCH 2 - AXIOLOGICAL APPROACHES TO CONTENT DEFINITION OF SPECIFIC GOALS IN THE EDUCATIONAL PROCESSES}

In content definition of education there is one significant ethical value status - pro-sociality. It is an important axiological dimension which is manifested in behaviour towards other people in the form of pro-social behaviour. The value-axiological dimension of pro-sociality lies in social and moral values of respect for oneself and others, for dignity, love, friendship, help and altruism. Pro-sociality is also an important moral quality in forming moral identity of pupils. It should be transformed into educational intention of contemporary schooling (content focus), into school value system and value orientation of pupils.

Aesthetic values also play substantial role in educational content. They are spiritual values which positively influence the quality of life, environment, relationships and are vital for preservation and development of culture and the understanding of other cultures. The basic aesthetic value is beauty, which is viewed as a sense of harmony, balance, happiness and joy. People merge with existence in unity with nature, society, people and themselves; they believe in the power of love, goodness and understanding (Kučerová, 1996, p. 130). Beauty has a lot of forms, it is aesthetically valued in material reality, it is expressed in art and outside art, it is an expression of aesthetic value of personal attitude based on emotions. Beauty is present, where there is creative activity to express intrinsic world based on perception, experience and evaluation of beautiful and ugly, noble and low, tragic and comic. These aesthetic categories determine one's relationship to the aesthetic.

${ }^{1}$ The results of analysis of global trends in determination of education fixed the second subject of discourses analysis - Axiological approaches to content definition of specific goals in the educational processes 
In the most comprised and intense form beauty is expressed through art. Art provides by technically perfected means a sense-perceptible demonstration of one's ideological-emotional coping with the world and life and their evaluation (Kučerová, 1996, p. 133). A value nature of art lies in the specific way of knowing reality. Art has a number of functions. The cognition aspect enables pupils to create a relationship to artistic values which forces pupils to act, express and evaluate artistic phenomena. A frequently overestimated aspect of education towards aesthetic values is the cognitive aspect. This is often encountered in aesthetic-educational subjects. If art is understood only as means of cognition, it affects pupils by its form and content. Aesthetic value of art and educational art lies in emotional experience and evaluation of people who reflect art by their aesthetic impressiveness based on emotions. They experience beauty in art as peculiar value reflecting value reality. Education towards art and aesthetic values in educational content enriches pupils not only by knowledge - allowing them to assess aesthetic phenomena - but also by the ability to treat phenomena, people and nature more sensitively. Pupils get higher sense of harmonious relationships in everyday life and beauty becomes a life necessity. Education towards aesthetic values stimulates pupils to aesthetic activities, creativity, originality of thinking and creating emotions and fantasies. Pupils become more open to other cultures and become capable of orientating in mass culture and pseudoculture. Education towards aesthetic values - towards beauty in everyday life and towards art - depends on general aesthetic education, which is reflected in evaluation attitude - the taste. It teaches pupils to orientate themselves in aesthetics and to be able to critically perceive various aesthetic values.

The understanding of aesthetic values deepens pupils' emotional relations to culture, human creations, phenomena and nature. If pupils accept aesthetic values, they provoke the need to accept aesthetic values when achieving harmony and overcoming obstacles. Aesthetic sensitivity helps pupils eliminate one-sided egocentric and utilitarian approach to culture and other values.

When forming a pupil's new value orientation and preferences of moral, aesthetic values in educational content an important part is played by values connected with environment and development - eco-social values. These are values which emphasize the value priority of nature for human life and human dependency on nature; human impact on all forms of life; keeping human activity within tolerable limits when exploiting resources; protective care of the environment; and rejecting consumerism. The understanding of the above mentioned ecological and environmental connections represents the basis for the development of ecological education and relationships towards the environment and nature. Teachers should help pupils form eco-social orientation based on positive understanding of the changes of the external system which depends on one's intrinsic world. The basis for accepting eco-social values is ecological knowledge which requires the use of rational, technical, ethical and aesthetic facts integrating the given issues into a coherent world view. It is necessary in the educational process to overcome mechanic understanding of the world and 
to enable pupils to know environment-related issues from the perspective of different subjects and inter-subject relations. The ecological and environmental concepts of education are creating the following new educational problems transforming on educational goals (Horká, 2000, p. 50).

The above mentioned issues form the foundation of ecological literacy based on which pupils form evaluating relations and active-practical skills for the environment. Eco-social orientation leads to the greater need to satisfy the spiritual dimension in human life; this is one way of improving the humankindenvironment relationship and creating harmony. Closely related is the endeavour to find the meaning of life. The content of ecological and environmental education incorporates also the values of health and healthy lifestyle. This type of education should be focused on performing the following roles:

- Holistic understanding of one's personality.

" Understanding of health values, healthy lifestyle, physical activity, nutrition, ecology, prevention etc.

- Basic knowledge of proper regimen, the quality and hygiene of nutrition, health risk factors, hygiene, stress, regeneration, stimulation.

- Basic knowledge of the rational use of free time

- Basic knowledge of primary drug prevention and the health impact of substance abuse.

- Basic knowledge of safe behaviour, life-threatening situations.

" Knowledge and abilities to maintain relationships to nature, people, health (Darák, 2004, p. 150).

School should see its educational function in acquiring knowledge and value orientation focused on the interiorization of values, health principles and healthy lifestyle. The presented roles must be reflected in the newly drafted process of education, educational content - particular content elements, which presumes efficient intervention for forming the life philosophy that health and healthy lifestyle strengthen one's own value and enables bigger cooperation with other environments.

In the end we would like to emphasize that axiological problems become more and more the centre of attention of contemporary education. Without axiological dimension in educational content it is neither impossible to imagine education of pupils, nor draft specific goals. Despite this fact, creating value systems in education is highly questioned. Value systems and value preferences are reduced to what can only be described concretely and used (cf. content and basics of RVP - General Educational Programme ${ }^{2}$ ). Educational content should or-

\footnotetext{
${ }^{2}$ Rámcový vzdělávací program abbreviated RVP - in English can be translated as General Educational Programme, in key competences and cross-section topics and methodical directives available at http://rvp.cz.
} 
ganise acquired values into specific taxonomic educational goals and value system which is typical for particular civilization as well as a concrete individual and it should direct pupils to these values. Values give human life a sense of meaning and represent a basis for value orientation of pupils and therefore have been dealt with in more detail although more on the theoretical level.

\section{RESULTS OF RESEARCH - RESULT OF THE DISCOURSE ANALYSIS: TAXONOMIC CLASSIFICATION OF GOALS}

Pedagogical conceptions are based on a hierarchic arrangement of cognitive areas presented as cognitive processes. This hierarchic arrangement is called taxonomy. Taxonomy of educational goals expresses a psycho-didactic approach of the teacher to the pupil during learning and educating and assists in the educational process and values development as well as determines goal activities of educational processes.

In the educational process the teacher recognizes general, specific and particular goals. Specific goals are considered inferior. They are expressed at the level of educational institution, in the profile of schools and educational facilities, in school plans or teacher's individual subject.

When defining goals, an emphasis is put on requirements which ensure the development of personal qualities in a particular activity and expected behaviour of pupils. Therefore educational goals must be formulated in a correct, clear, unambiguous and concise way. A very important requirement is adequacy which determines the level of pupils' performance. There must be a possibility to monitor goals in order to allow checking acquired knowledge and the level of changes which might arise. The last requirement is the consistency of goals which expresses the sequence of goals ranging from the lowest up to the highest, from specific to general, from close to distant. New trends, alternative or special programmes require the teacher to specify and formulate goals with regard to specific requirements of these programmes. Educational goals fulfil a number of functions in the educational process. The basic functions are: orientation, motivation, realization and regulation. Other functions are: information, innovation, prognosis and axiology (Kročková, 2004, p. 62). The understanding and classification of goals and their functions is the first theoretical prerequisite to manage educational process and eliminate frequent phenomena such as formalism, subjectivism, randomness, improvisation and one-sidedness. 


\subsection{Results of Research Particular 1: traditional taxonomic classification of goals}

Pedagogical conceptions which present the taxonomy of goal qualities in gradual development of personality on the cognitive level were designed by B. S. Bloom et al. They suggest the following methodical procedures during teaching and class management:

1. Acquiring knowledge and information.

2. The understanding based on intellectual operations which enable pupils to understand, clarify, sort and generalize.

3. Applying acquired and understood knowledge in particular situations; using generalization, theories, laws, rules etc.

4. Teaching - based on intellectual abilities - how to analyze, divide, determine the causes and consequences.

5. Developing abilities to synthesize, generalize, conclude, hypothesize.

6. Developing evaluational thinking based on acquired and accepted criteria; decide, defend, plan and produce (Turek, 2004, p. 45).

\subsection{Results of Research Particular 2: traditional taxonomic classification of goals}

In a similar manner, authors have tried to construct taxonomies for the development of non-cognitive area - affect and psycho-motoric aspect of a person. This concerns development of goal qualities which are demonstrated in the abilities of being emphatic, being able to react to stimuli and being able to intrinsically process them, take a stance based on accepted and adopted criteria up to the self-realization of a person. The taxonomy of goal development qualities has been conducted by D. R. Krathwohl, H. Daeve, B. Niemierko, B. B. Masia, E. F. Williams, C. Rogers.

The authors have created - based on models - an arrangement and links between psychic functions and processes into certain units. The taxonomy of goal qualities in affective area (on Czech and Slovak pedagogical theory) has been organized hierarchically into five steps:

" Internalization

Creating terminology

$\rightarrow$ Evaluation

- Response, reaction

Acceptance (Zelina, 1996, p. 32). 
Taxonomic arrangement in educational work must be developed on all levels of cognitive and non-cognitive development from emotions, feelings, motivation and creating own values to character and moral steadiness and self-updating. This area is extremely subjective, however, it is important for the educated to accept those values which are essential for his/her emotional and social life.

The above mentioned taxonomies in non-cognitive areas are meant to point out that the development of cognitive sphere is not possible without emotions, motivation and values; otherwise this process becomes spontaneous and random. Even though we are aware that taxonomies of goals for educational work include more than we have mentioned, our intention is to prevent neglecting of value-emotional education. It is also important to elevate educational work of teachers, educators, social teachers or teachers' assistants to higher scientific level.

\section{CONCLUSIONS}

The educational goals in Czech and Slovak pedagogy can be found in the areas of philosophy and the theory of education. The core of the matter is teleology, which deals with the most general educational goals. Many experts study and explain this issue from different perspectives. We must be aware of historical background, which is closely related to cultural conditioning of educational goals. Methodological and methodical point of view defines general and specific educational objectives. It is based on the educational conception of contemporary pedagogy, the theory of education, philosophy of education and deals with educational content. The political view of this issue is related to very important person - Maria Theresa, who introduced contemporary school attendance. Currently, there is a new concept of educational goals in the EU context. Global bases of educational goals arise from contemporary society, value system and aspect of globalization. Philosophical bases represent the notion of the educational goal as the core of the educational process. The goal can be structured hierarchically and can be motivation as well. The aim of society is to bring up individuals who are competent, intelligent, and empathetic and who participate in social life. Contemporary society need people who are able to change the job, adapt to new conditions, are flexible, motivated, are able to learn new things and function in everyday life.

The goal in axiological dimension is not only value of self-esteem but especially moral values and pro-social behavior. Pro-sociality should be integrated into school value system and value orientation of pupils. Value system is an important component of human history and development. In the process of forming pupil's value orientation, we must highlight moral, aesthetic values as well as eco-social values. We should maintain the holistic point of view, thus develop aesthetic values and simultaneously support the value priority of nature and protect environment. Schools should permanently support and form value orientation of pupils which is focused on the exteriorization of values, health principles and healthy lifestyle. 
Cognitive processes are based on a hierarchic arrangement of cognitive areas called taxonomy. Taxonomy of educational goals refers to a psycho-didactic approach of the teacher to the pupil; it supports the educational process and development of values as well as identifies the objectives of educational processes. The teacher differentiates general, specific and particular goals. The educational goals must be formulated in a correct, concrete and unambiguous way. They should be also controllable. The educational goals set the requirements which ensure the development of personality on the cognitive, affective and psychomotoric level.

The educational goals are essential and significant part of teacher's profession. They facilitate educational processes as well as teacher's career, are innovative, flexible and adaptable. The teacher can set the goals which form pupil's knowledge, skills as well as attitudes. In the condition of present school we should not concentrate only to knowledge but also to moral values and cultivate pro-social behavior of pupils.

\section{List of literature and professional sources}

Bábosik, I. (1997) A modern neveléš elmétete. Budapešt': Telosz.

Bíla kniha o mládeži -Národni konference. (2001). Praha: MŠMT - IDM - Česká agentura mládeže.

Blížkovský, B. (1992) Úvod do pedagogiky - Pojetí výchovy. Brno: PdF MU.

Brezinka, W. (1991). Dnešná rodinná výchova - potreba presviedčenia o hodnotách. Pedagogická revue, vol. 43, issue 8, p. 586.

Brezinka, W. (1996). Filozofické základy výchovy. Praha: SPN.

Brezinka, W. (2001).Východiska k poznání výchovy. Brno: L. Marek.

Darák, M. (2004). Kapitoly z teórie výchovy. Prešov: FHaPV.

Delors, J. (Ed.) (1996). Learing: The Treasure Within. Report to UNESCO of the International Commission on Education for the Twenty-first Century. Paris: UNESCO Publishing.

Gogová, A. \& Kročková, Š. \& Pintés, G. (2004). Žiak, Sloboda, Výchova. Prešov: Vydavatel'stvo M. Vaška.

Horká, H. (2000) Výchova pro 21. stoleti: Koncepce globální výchovy v podmínkách české školy. Brno: Paido.

Chudý, Š. a kol. (2006). Hledáni kořenů výchovy v současné společnosti: koncepce, úvahy, názory a dilemata. Brno: Paido.

Janiš, K. \& Kraus, B. \& Vacek, P. (2008). Kapitoly ze základů pedagogiky. Hradec Králové: Gaudeamus.

Jůva, V. sen. \& jun. (1997). Stručné dějiny pedagogiky. Brno: Paido.

Kaščák, O. \& Pupala, B. (2009). Výchova a vzdelávanie v základných diskurzoch. Prešov: Rokus.

Kot’a, J. (2009). Filozofia výchovy. In Pedagogická encyklopedie. Praha: Portál. 
Kročková, Š. (2001). K problematike výchovných ciel'ov a formovania správania sa žiakov. In Škola a súčasnost'. Nitra: UKF PF.

Kučerová, S. (1990, 1994). Úvod do pedagogické antropologie a axiologie. Brno: MU. Kučerová, S. (1996). Člověk - hodnoty - výchova. Prešov: MANACON.

Kudláčová, B. (2004). Premeny človeka a výchovy v kontexte dejín európskeho myslenia. Pedagogická revue, vol. 56, issue 2, pp. 121-122.

Kudláčová, B. (2007). Človek a výchova v dejinách európskeho myslenia. Trnava: PdF TU. Learning: The Treasure Within-Report to UNESCO of the International Commission. (1996). Učení je skryté bohatství. Zpráva mezinárodni komise UNESCO „Vzděláni pro 21. stoleti“. (1997). Praha: Ústav pro informace ve vzdělávání.

Lorenz, K. (1990). 8 smrtelných hř́chů. Praha: Pyramida.

Patočka, J. (1997). Filosofie výchovy. Edited by Radim Palouš. Praha: PF UK.

Palouš, R. (1991). K filosofii výchovy: (východiska fundamentální agogiky). 1. vyd. Praha: SPN.

Pintes, G. (2005). Teleológia ciel'ov výchovy. In Multidimenzionálne aspekty výchovy a vzdelávania. Nitra: UKF.

Pelcová, N. (2004). Filozofická a pedagogická antropologie. Praha: Karolinum.

Pelikán, J.(1995). Výchova jako teoretický problém. Ostrava: Amosium servis.

Pelikán, J. (1997). Výchova pro život. Praha: ISV.

Rajský, A. (2007). Filozofické aspekty výchovy a vzdelávania. In Úvod do pedagogiky. Trnava: PdF TU.

Rosa, V. \& Turek, I. \& Zelina, M. (2000). Návrh koncepcie rozvoja výchovy a vzdelávania v SR. /Projekt „Milénium“\%. Učitel'ské noviny, vol. 50, issue č. 3.

Skalková, J. (2004). Pedagogika a výzvy nové doby. Brno: Paido.

Stark, S., Demjančuk, N. \& Demjančuková, D. (2003). Kapitoly z filozofie výchovy. Dobrá voda: Aleš Čeněk.

Střelec, S. (2005). Studie z teorie a metodiky výchovy II. BRNO: MU.

Štverák, V. (1999). Obecná a srovnávací pedagogika. $1^{\text {st }}$ ed. Praha: Karolinum.

Švec, Š. (2001). Učit' sa byt' a uspiet'. Pedagogická revue, vol. 53, issue 1, pp.14-18.

Švec, Š . (1995). Základné pojmy v pedagogike a andragogike. $1^{\text {st }}$ ed. Bratislava: IRIS.

Švec, Š. (2000). Teoreticko-metodologické základy andragogiky. In Paedagogica 15 zbornik FF UK. Bratislava: UK.

Švec, Š. a kol. (1998). Metodológia vied o výchove: kvantitatívno-scientické a kvalitatívno-humanitné prístupy. Bratislava: Vydavatel'stvo IRIS.

Turek, I. (2004). Inovácie v didaktike. Bratislava: MPC.

Turek, I. \& Zelina, M. \& Rosa, V. (2002). Národný program výchovy a vzdelávania v Slovenskej republike na najbližšich 15 až 20 rokov. Bratislava: MŠSR.

Višňovský, L. (1998). Teória výchovy (vybrané kapitoly). Banská Bystrica: UMB.

Zákon č. 254/2008 o výchove a vzdelávani (školský zákon).

Zákon č. 561/2004 Sb., o předškolním, základním, středním, vyšším odborném a jiném vzdělávání (Školský zákon).

Zelina, M. (1996). Stratégie a metódy rozvoja osobnosti diet'at’a. Bratislava: IRIS. 


\section{Contacts:}

Mgr. Štefan Chudý, Ph.D.

PaedDr. Alena Jůvová, Ph.D.

Mgr. Pavel Neumeister, Ph.D.

Mgr. Denisa Snopková

Institute of Education and Social Studies

Faculty of Education, Palacký University Olomouc

Žižkovo nám. 5

77140 Olomouc

Czech republic

E-mail: stefan.chudy@upol.cz, Phone: +420-585 635161

E-mail: alena.juvova@upol.cz, Phone: +420-585 635144

E-mail: pavel.neumeister@upol.cz, Phone: +420-585 635161

E-mail: denisa.snopkova@upol.cz,Phone:+420-585 635161 